\title{
Rainfall-Runoff Simulation Using HEC-HMS Model in the Benanain Watershed, Timor Island
}

\author{
Wilhelmus Bunganaen', John H. Frans ${ }^{1}$, Yustinus A. Seran ${ }^{1}$, Djoko Legono², Denik Sri \\ Krisnayanti $^{{ }^{*}}$ \\ 1Department of Civil Engineering, Nusa Cendana Universitas, Kupang, INDONESIA \\ Jalan Adi Sucipto Penfui Kupang \\ ${ }^{2}$ Department of Civil and Environmental Engineering, Universitas Gadjah Mada, Yogyakarta, INDONESIA \\ Jalan Grafika No 2 Yogyakarta \\ *Corresponding authors: denik.krisnayanti@staf.undana.ac.id
}

SUBMITTED 18 March 2021 REVISED 11 July 2021 ACCEPTED 02 August 2021

\begin{abstract}
Floods in a watershed area are caused by reduced water recharge due to changes in land use, increasing their discharge volume. Benanain watershed is an extensive area with many tributaries. Watershed morphometrics provides initial information about the hydrological behavior and the hydrograph shape of flooding in these areas. Furthermore, rainfall-runoff modeling uses as a unit to approach the hydrological values of the flooding process. This study determines the physical characteristics of the Benanain watershed based on curve number $(C N)$ values, land cover, peak discharge, and peak time. It was conducted on the Benanain watershed with 29 subwatersheds covering 3,181.521 km². Data were collected on the rainfall experienced for 13 years from 1996 to 2008 and analyzed using the Log Pearson Type III method, while the HEC HMS model was used for flood discharge analysis. HEC-HMS model must calibrate by adjusting the model parameter values until the model results match historical data such as initial abstraction, lag time, recession, baseflow values, and curve number. The results show that the curve number values range from $56.55-73.90$, comprising secondary dryland forest and shrubs. Moreover, the rock lithology in the Benanain watershed is dominated by scaly clay and other rock blocks. This means the area has low to very low permeability, which affects the volume of runoff. The return period of a 1000-year flood discharge obtained a peak of $5,794.50 \mathrm{~m}^{3} / \mathrm{s}$, with a peak time of \pm 14 hours. Morphometry of the Temef watershed with large catchment, radial shape pattern, an average of steep slope river, and meandering affects the peak of flood discharge hydrograph and the peak time of the flood.
\end{abstract}

KEYWORDS Run off; Curve Number; Radial; Permeability; Rock Lithology.

(c) The Author(s) 2021. This article is distributed under a Creative Commons Attribution-ShareAlike 4.0 International license.

\section{INTRODUCTION}

A watershed is a catchment area with a unit river and tributaries accommodating, storing, and flowing water from rainfall to lakes or the sea. The land boundary is known as topography, while the sea boundary consists of the water areas affected by land activities (UU No. 7, 2004). Additionally, a watershed could be considered a hydrological unit because it converts rainfall (input) into runoff (output), sediment, and nutrients. The rainfallrunoff is a very complex scientific process influenced by several factors. Chow et al. (1998) explained that climatic and physiographic factors have the most significant influence on rainfallrunoff. Climatic factor includes the relation between rainfall and evapotranspiration, while physiographic factor influences comprise river and watershed characteristics. Rainfall is an important meteorological parameter to determine river flow discharge. Furthermore, the runoff is influenced by the watershed's physical characteristics, including land use and soil. The watershed physical parameter could be expressed as an index of a curve number $(C N)$. According to McCuen (1998), the $C N$ value shows the effect of hydrology on soil, land use, and soil moisture.

Surface runoff is needed to determine the potential of water resources in the watershed. Tivianton (2008) stated that river flow discharge is the total surface runoff, rainwater directly falling on the river body, intermediate flow, and baseflow, measured at the river outlet point. The 
flood hydrograph is used to analyze watershed rainfall-runoff watershed. According to Sene (2008), flood hydrographs are useful for studying river volume fluctuations and the discharge peak time to obtain a relationship between rainfall and river flow discharge by return period.

Some ungauged watersheds have insufficient flow data to be used in expressing flood hydrographs due to field conditions. In this case, quantitative analysis is carried out using a hydrological model. The Hydrologic Engineering Center - Hydrologic Modeling System (HEC-HMS) was developed by the U.S. Army Corps of Engineers (USACE) to simplify complex watershed systems. This assumption must be fulfilled for the model's input and output to suit the actual watershed system. Therefore, HEC-HMS simulates the flow calculation based on rainfall and watershed characteristics as input components. The watershed characteristics include morphometric aspects, land use, and soil conditions.

Several previous studies examined smaller watershed rainfall-runoff simulation in Indonesia using the HEC-HMS model (Sarminingsih et al., 2019; Anggraheni et al., 2018; Delani et al., 2016). HEC-HMS is used widely with ArcGIS 10.5 software in spatial-based hydrological simulation with distributed data, continuous flow models, and calibration facilities. This software initially calculates losses, transformation (hydrograph unit), baseflow, and flood routing (Adidarma, 2013). Moreover, the Soil Conservation Service method shows the difference between total rainfall and actual evapotranspiration. It is useful in areas with rainfall but no flood hydrograph data, such as the Benanain watershed, due to lack of observation discharge or automatic water level recorder (AWLR).

The Benanain river is one of the largest and longest in East Nusa Tenggara Province (NTT), covering around $3181.521 \mathrm{~km}^{2}$. The length of the main river is about $128 \mathrm{~km}$ and has around 92 tributaries. There are 13 large and 79 small rivers, while the Benanain river flows across four districts, including South Central Timor (TTS), North Central Timor (TTU), Malaka Regency, and
Belu Regency. Its upstream is in the TTS, TTU, and Belu regencies, while the downstream is in the Malaka Regency, flowing into the Timor Sea.

Benanain river overflows almost annually and sometimes more than once a year, depending on the upstream rainfall intensity. The maximum runoff (floods) is caused by several factors, including high-intensity rain and the river's reduced cross-sectional capacity. Subsequently, the river channel dimensions become insufficient to accommodate the river flow. This results in overflows that inundate residential homes in West Malaka District.

Control efforts are needed to reduce the damage caused by floods in the watersheds, though this requires prior knowledge on flood discharge. Therefore, this study determines the physical characteristics of the Benanain watershed based on curve number $(C N)$ values, land cover, peak flood discharge, and time. It uses the Hydrologic Engineering Center-Hydrologic Modeling System (HEC-HMS) Modeling.

\subsection{Flood Hydrograph Analysis with the HEC-HMS Model}

HEC-HMS (Hydrologic Engineering Center Hydrologic Modeling System) software was developed by the U.S Army Corps of Engineering. It is a mathematical model that simulates the rainfall-runoff of a dendritic watershed system with basin and meteorologic models, as well as control specifications and data input (Bimtek Balai Bendungan, 2019).

HEC-HMS uses a synthetic unit hydrograph calculation method with measured and model flood hydrographs. The measured flood hydrograph was developed using the rainfallrunoff data. In comparison, the flow discharge is determined by the automatic water level recording (AWLR), using the rating curve equation. Additionally, this synthetic unit has several choices methods, such as the Soil Conservation Service Unit Hydrograph (Suhartanto, 2008). This method is accepted and applied because it is predictable and conceptually stable. Also, it has been tested and analyzed based 
on its capabilities, limitations of use, as well as conceptual and empirical validity (Moglen 2000; Mishra et al. 2013; Banazik et al., 2014; ZeenatAra \& Zakwan, 2018).

The Soil Conservation Services method with a Curve Number estimates cumulative rainfall, land cover and use, and previous soil moisture. Curve Number $(C N)$ is a function of the total rainfall thickness and a parameter for the runoff curve. $C N$ values range between 1 and 100 as a runoff function resulting from basins or raised areas, such as hydrological soil types (NEH, 2004a), land use (NEH, 2004b), soil surface, and previous soil moisture (Adidarma, 2013; Ramadan et al., 2017; Rao, 2020).

Table 1. Hydrological Soil Group Based on USDA Soil Classification

\begin{tabular}{ll}
\hline HSG & Soil Texture \\
\hline A & Sand, loamy sand, or sandy loam \\
B & Silt or loam \\
C & Sandy clay loam \\
D & Clay loam, silt clay loam, sandy clay, or clay \\
\hline
\end{tabular}

Source: NEH, 2004a

\subsection{The Curve Number from Rainfall-Runoff Data}

The empirical formula used is shown in Equation (1).

$P_{e}=\frac{(P-I a)^{2}}{P-I a+S}$

where $P_{e}$ is the accumulated runoff at time t $(\mathrm{mm})$, $P$ is the accumulated rainfall at time $t(\mathrm{~mm}), I a$ is the initial abstraction or loss ( $\mathrm{mm}$ ), and $S$ is the potential maximum retention of rain in the watershed following the fulfillment of $I a(\mathrm{~mm})$. Initial abstraction is the amount of rainfall that wets the soil surface, including crops, trash, and vacant land before actual infiltration begins. The empirical equations of $I a$ and $S$ are linked linearly by $\lambda$, which is equal to 0.2 (Equation (2)).

$I a=0.2 S$

Excess of rainfall during the $\Delta t$ interval is the difference between accumulative rainfall at the end and beginning of the period. The potential maximum retention, $S$, and watershed characteristics were related to the intermediate parameter in Equation (3).
$S=(25400-254 C N) / C N$

The SCS UH method determines the peak time $\left(t_{p}\right.$, time to peak) and peak discharge $\left(Q_{p}\right)$ shown in Equation (4) (USACE, 2000):

$\mathrm{Q}_{\mathrm{p}}=\mathrm{C} \frac{\mathrm{A}}{\mathrm{t}_{\mathrm{p}}}$

Where $A$ is the watershed area, and $C$ is the constant conversion (2.08 in the SI and 484 in the leg system). The peak time to the duration of the rainfall is shown in equation (5).

$\mathrm{T}_{\mathrm{p}}=\frac{\Delta \mathrm{t}}{2}+\mathrm{t}_{\text {lag }}$

Where $\Delta t$ is the rainfall duration (hour) and $\mathrm{t}_{\text {lag }}$ is the time lag (hour). The equation for the time lag in hours is shown in Equation (6).

$\mathrm{t}_{\text {lag }}=\frac{L^{0,80} \times(2540-22,86 \times C N)^{0,70}}{14104 \times C N^{0,70} \times Y^{0,50}}$

where $L$ is the hydraulic length (the distance along the mainstream to the furthest point in meter units), $Y$ is the mean slope of the watershed $(\mathrm{m} / \mathrm{m})$, and $C N$ in the Curve Number.

\section{METHODS}

The Benanain watershed area is located on the island of Timor at the coordinate position of $124^{\circ} 11^{\prime} 45.64^{\prime \prime}-125^{\circ} 07^{\prime} 31.22^{\prime \prime} \mathrm{E}$ and $8^{\circ} 56^{\prime} 33.21^{\prime \prime}$ LS - $9^{\circ} 58^{\prime} 34.60 " \mathrm{~S}$ (Figure 1). The data used in this study include:

a) Primary data:

Documentation and survey of flood questionnaires on local residents.

b) Secondary data:

Rainfall data and map data consist of:

1) Land cover map

2) Maximum daily rainfall from 1996-2008 (Balai Sungai Nusa Tenggara II)

3) Coordinates for the location of the rainfall station (Balai Sungai Nusa Tenggara II)

4) Map of the division of the UTM Zones in the Indonesian Territory

5) Indonesian Hydrogeological Map (Directorate of Environmental Geology) 


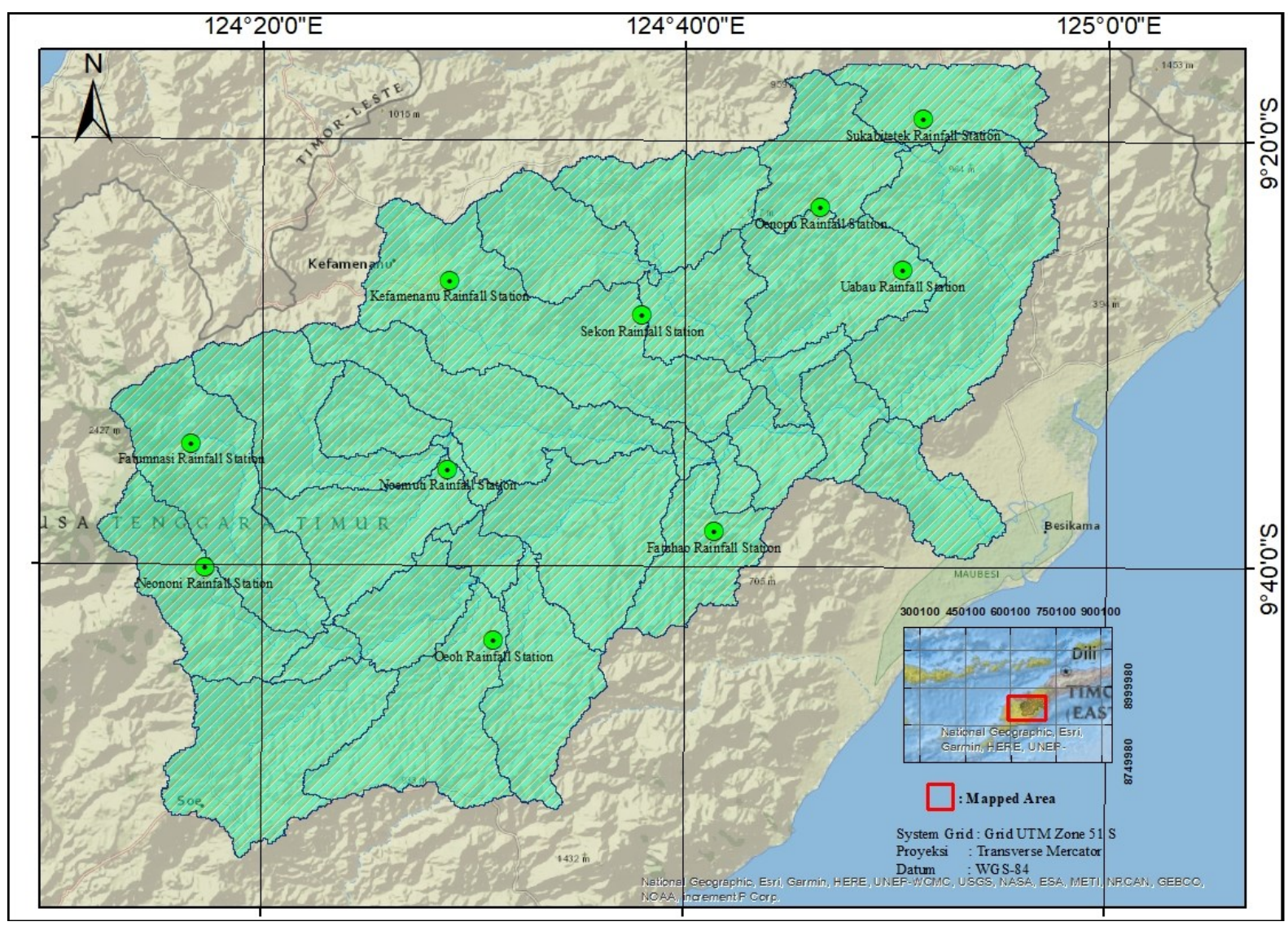

Figure 1. Location Map of Benanain Watershed.

ArcGIS 10.5 software digitization data consists of:

1) Data Digital Elevation Model / DEM (Software Global Mapper v.18)

2) The outlet points of the Benanain watershed (Google Earth)

The steps of the research carried out were as follows:

a) Hydrological analysis by collecting rainfall data for 13 years (1996-2008) from ten rainfall stations in the Benanain watershed, as shown in Figure 1.

b) Digitizing watershed parameters, including boundaries, area, length of the main river and tributaries, number of confluences, slope, watershed width, and basin modeling with the ArcGIS 10.5 software.

c) Digitizing land cover and hydrological soil grouping. This step involves calculating the curve number value by diversifying from a hydrogeological to a hydrologic soil group map.

d) Calculating the flood discharge using the Soil
Conservation Service Curve Number (SCS$\mathrm{CN}$ ) method with the software tools of the Hydrologic Engineering Center-Hydrologic Modeling System (HEC-HMS) 4.3.

\section{RESULTS}

\subsection{Hydrology Analysis}

The calculation of rainfall distribution for the Benanain watershed uses four methods for each station. These are the Normal distribution method, Log-Normal, Log-Pearson Type III, and Gumbel. The results were obtained by the goodness of fit test with the chi-square and Smirnov Kolmogorov. The recapitulation of the design rainfall analysis is in Table 2.

Triatmodjo (2008) stated that the distribution to be used must adjust to the requirements of skewness coefficient $(C s)$, variation coefficient $(C v)$, and kurtosis coefficient $(C k)$ according to Table 3. Digitization using ArcGis 10.5 resulted in the Benanain watershed area of $3,181.521 \mathrm{~km}^{2}$, divided into 29 sub-watersheds from W-300 to W580, as shown in Figure 2. 
Table 2. Recapitulation of Design Rainfall by Return Period Using Various Methods in the Benanain Watershed

\begin{tabular}{llll}
\hline Return Period (Years) & Normal distribution & Log-Normal Distribution & Log-Pearson Type III Distribution \\
\hline 2 & 77.85 & 71.42 & 72.77 \\
5 & 104.96 & 103.59 & 104.13 \\
10 & 119.16 & 125.87 & 124.26 \\
25 & 132.98 & 152.15 & 148.93 \\
50 & 144.01 & 177.00 & 166.75 \\
100 & 153.05 & 200.36 & 184.03 \\
500 & 170.80 & 255.60 & 212.42 \\
1000 & 177.57 & 280.51 & 239.62 \\
\hline
\end{tabular}

Table 3. Statistical Parameter Test

\begin{tabular}{lll}
\hline \multirow{2}{*}{ Distribution } & \multicolumn{2}{c}{ Parameters } \\
\cline { 2 - 3 } & Required & Obtained \\
\hline Normal & $C s=0.0000$ & $C s=0.2300$ \\
& $C k=3.0000$ & $C k=0.0015$ \\
\hline Log-Normal & $C s / C v=3.00$ & $C s / C v=-2.45$ \\
\hline Gumbel & $C s=1.1396$ & $C s=0.2300$ \\
& $C k=5.4002$ & $C k=0.0015$ \\
\hline Log-Pearson Type III & - & $C s=-0.2500$ \\
& & $C k=0.1000$ \\
\hline
\end{tabular}

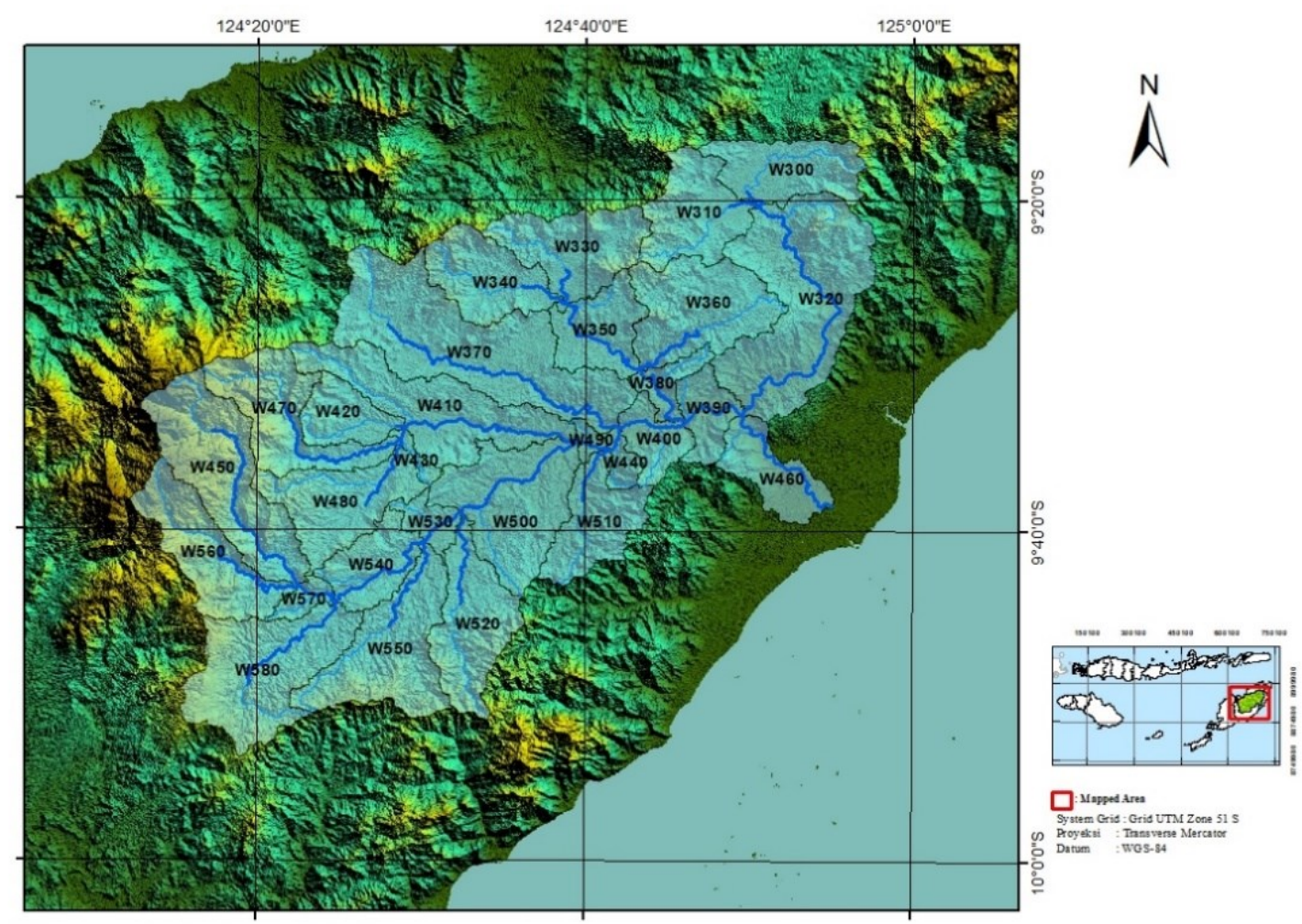

Figure 2. The Map of Benanain Sub-Watershed.

\subsection{Analysis of Land Cover and Curve Number $(C N)$ Value of the Benanain Watershed}

The curve number value represents the watershed physical characteristics of soil, hydrological conditions, land use, and antecedent moisture condition (AMC). The Land Use Map of the island of Timor could be used to classify and analyze the land use of the Benanain watershed using ArcGIS 10.5 software. The Benanain watershed has 9types of land cover, including primary and secondary dryland forest, agriculture, shrubs, savanna, scrub, open land, settlement, and water 
bodies. The $C N$ value was determined using the SCS-CN method by combining land use with the Hydrologic Soil Group (Krisnayanti et al., 2021). Additionally, the soil hydrology group is divided into A, B, C, and D based on their textures. The external texture determines the hydrological group because it relates to the soil's effective water capacity and affects infiltration. The results from the calculation of curve number analysis for the 29 sub-watersheds are shown in Figure 3.

\subsection{Surface Runoff in the Benanain Watershed}

Flood hydrograph analysis with the HEC-HMS model involved determining the highest single peak flood hydrograph events and a single rain during a certain period. According to Ponce (1989), the intensity rainfall greater than $10 \mathrm{~mm}$ is considered heavy rain, possibly causing floods. It is necessary to fill hydrological parameters in the HEC HMS, including basin and meteorological models, control specifications, time-series data, losses, transform base flow, and river routing. These parameters are needed to determine the flood discharge value by return period in the Benanain watershed. The recapitulation flood discharge design for various returns periods (W460) is shown in Table 4. The results in Table 4 were then plotted into then in Figure 4.

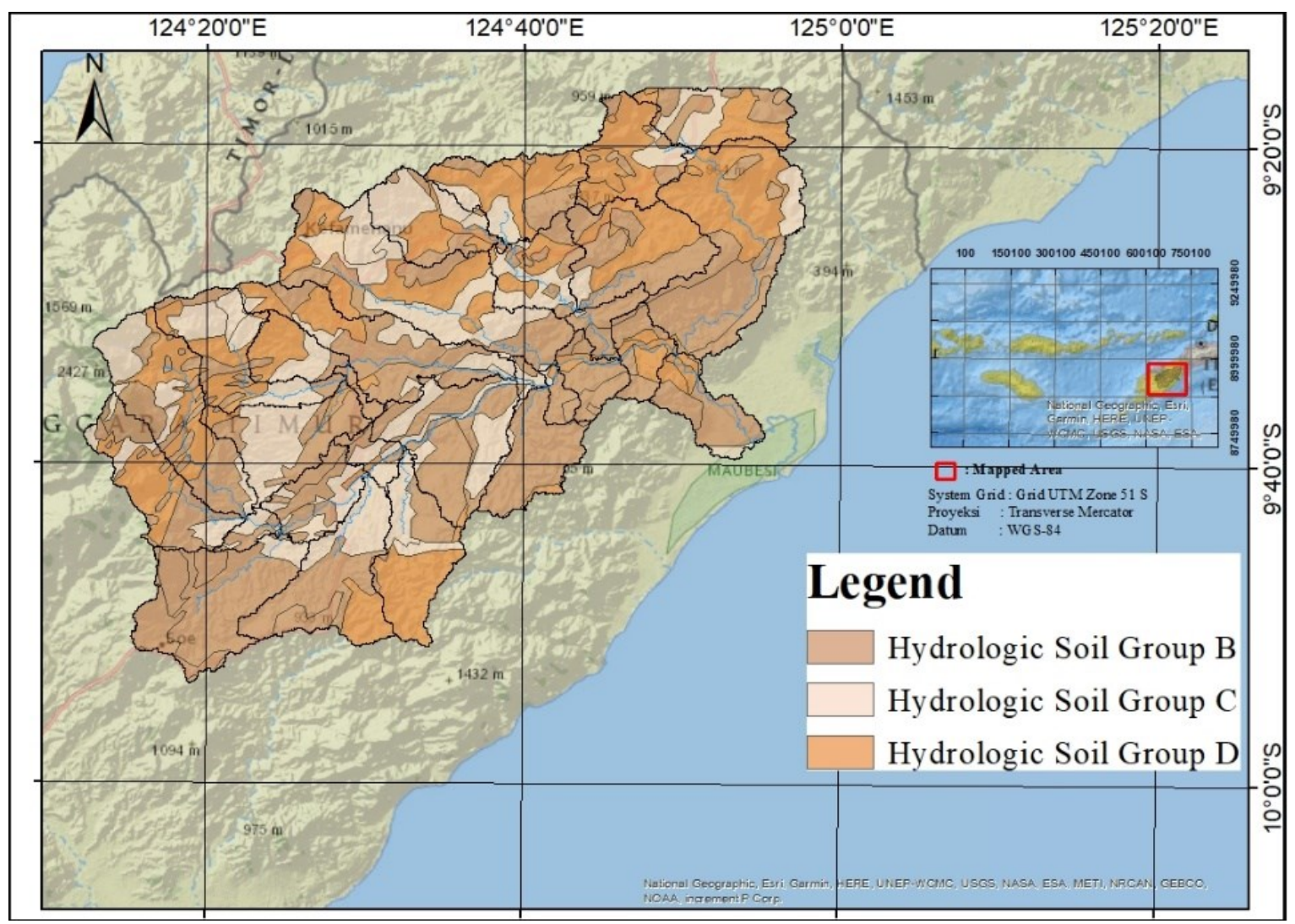

Figure 3. Hydrologic Soil Group (HSG) map in the Benanain watershed

Table 4. Recapitulation of flood discharge by return period in the Benanain watershed

\begin{tabular}{llll}
\hline No & Return Period (Years) & Flood Discharge $\left(\mathrm{m}^{3} / \mathrm{s}\right)$ & Inflow from W- $460\left(\mathrm{~m}^{3} / \mathrm{s}\right)$ \\
\hline 1 & 2 & 507 & 495 \\
2 & 5 & 1138 & 1106 \\
3 & 10 & 1631 & 1583 \\
4 & 25 & 2304 & 2225 \\
5 & 50 & 2835 & 2730 \\
6 & 100 & 3407 & 3265 \\
7 & 500 & 4619 & 4405 \\
8 & 1000 & 5794 & 5493 \\
\hline
\end{tabular}




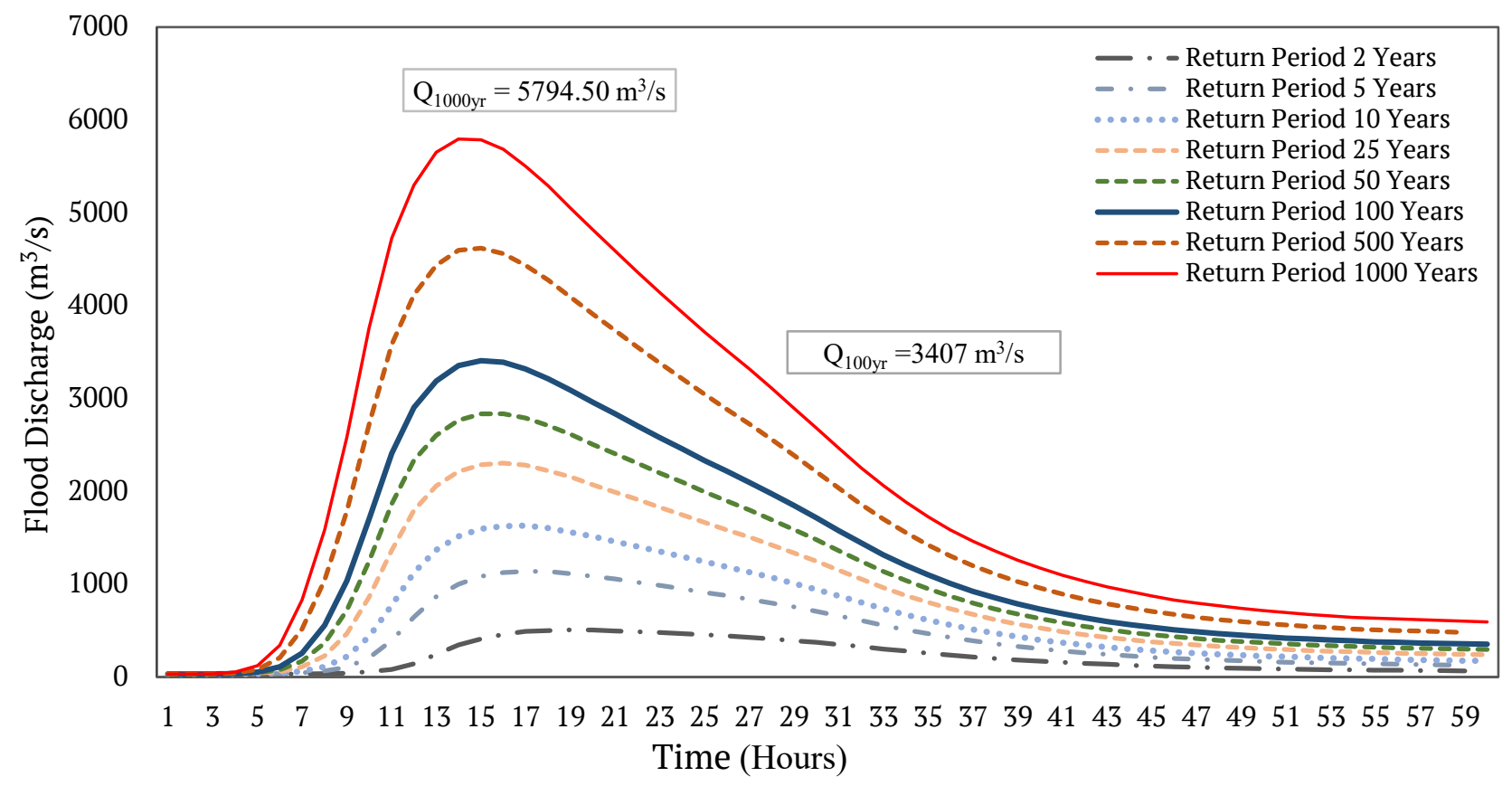

Figure 4. Design Flood Discharge by Return Period of 2 - 1000 Years in the Outlet of Benanain Watershed

\section{DISCUSSION}

The Log-Pearson Type III distribution is a statistical technique used in hydrology analysis from the four methods in Table 2. It fulfills the required statistical tests and has no limit value on the coefficient of variation $(C v)$ and the coefficient of skewness $(\mathrm{Ck})$. The calculations using this method obtained a coefficient of variation $(C v)$ of 0.10 and the coefficient of skewness $(C s)$ of -0.25 . Therefore, the method is useful in calculating the design flood discharge by a return period of 2-1000 years.

The land cover in the Benanain watershed is dominated by secondary dryland forests and shrubs, with respective percentages of $44.26 \%$ and $22.53 \%$. Open land cover and water bodies had the smallest percentages of $1.00 \%$ and $0.01 \%$, respectively. Furthermore, Figure 3 shows that the $C N$ value of the Benanain watershed ranges from 56.55 to 73.90. The largest $C N$ is in subwatershed W-310, dominated by scaly clay, rock boulders, and shrubs. The smallest $C N$ is in subwatershed $\mathrm{W}-510$, covering $87.98 \mathrm{~km}^{2}$ or $0.91 \%$. The area is dominated by sandy marl interbedded with sandstone, conglomerates, dacitic tuff, and open forest land cover.

Figure 4 shows that the flood discharge for a 1000 -years return period is $5,794.50 \mathrm{~m}^{3} / \mathrm{s}$ with a peak time of \pm 14 hours. The Benanain watershed is radial or fan-shaped, and its tributaries are concentrated at an outlet downstream. Watersheds with this pattern often have heavy flooding near the tributary's outlet points. This study shows discharge values similar to the previous research, using different methods in the same area. For instance, Balai Wilayah Sungai NT II (2014) examined the flood discharge in the Benanain watershed using the Nakayasu and Snyder Synthetic Unit Hydrograph methods. The study focused on the flood design for a 100-year return period and obtained 3,635.00 - 3,959.00 $\mathrm{m}^{3} / \mathrm{s}$. In comparison, this study analysis found that the 100-year return period for Benanain watershed flooding was $3,407.10 \mathrm{~m}^{3} / \mathrm{s}$. The insignificant disparity in these results was influenced by different input parameters for each method used.

Flood discharge occurs because the Benanain watershed covers around $3,181.521 \mathrm{~km}^{2}$, with curve numbers ranging between 56.55 and 73.90. Furthermore, the hydrogeological map of Timor Island shows that the Benanain watershed is dominated by scaly clay and other rock blocks. The area has low to very low permeability, affecting runoff compared to water infiltration. The watershed morphometrics, such as land 
cover, soil type, area, slope, shape, and river patterns, provide relevant initial information about the flood hydrograph. However, the results of this simulation discharge would be better when calibrated with field observations. The unavailability and unreliable observation discharge data is an obstacle in calibrating with the simulation discharge. Therefore, it is necessary to calibrate the simulation discharge against the observation discharge for further analysis.

\section{CONCLUSION}

The Benanain river is one of the largest and longest in NTT Province, divided into 29 subwatersheds. Its land cover is dominated by secondary dryland forest and shrubs, with respective percentages of $44.26 \%$ and $22.53 \%$. Moreover, the watershed's lithology is dominated by scaly clay, containing other rock blocks with low to very low permeability. The area is classified under the HSG D group, with an area percentage of $25.667 \%$. The 1000 -year return period of flood discharge using SCS CN obtained a peak discharge of $5,794.50 \mathrm{~m}^{3} / \mathrm{s}$. It is the same as the discharge analyzed by previous studies of $7-15 \%$ from the simulation discharge using the HEC-HMS model and the SCS-CN method. However, this simulation would be better when calibrated with field observations. Moreover, the long rainfallrunoff record data would show a better comparison between the HEC-HMS model results and actual conditions.

\section{DISCLAIMER}

The authors declare no conflict of interest.

\section{AVAILABILITY OF DATA AND MATERIALS}

All data are available from the author.

\section{ACKNOWLEDGMENTS}

The authors thank the Civil Engineering Department at Nusa Cendana University and Balai Wilayah Sungai NT II for supporting this research.

\section{REFERENCES}

Adidarma, W. K., 2013. Teknik Perhitungan Banjir Desain untuk Bendungan Menggunakan Metode NRCS (Technique to Determine Inflow of Planned Flood for Dams Using the NRCS Method). Jurnal Teknik Hidraulik, 4(2), pp.105-116.

Anonim, 2004. Undang-Undang Nomor 7 Tahun 2004 Tentang Sumber Daya Air. Jakarta.

Anggraheni, E., Sutjiningsih, D. \& Widyoko, J., 2018. Rainfall-Runoff Modeling Calibration on the Watershed with Minimum Stream Gage Network Data. International Journal of Engineering \& Technology, 7 (3.29), pp.121-124

Balai Bendungan, 2019. Bimbingan Teknis Perhitungan Debit Banjir pada Keterbatasan Data Curah Hujan. Penjelasan Umum Aplikasi HECHMS. Palembang

Balai Wilayah Sungai NT II, 2014. Laporan Akhir Detail Desain Bangunan Pengendali Banjir Di Kabupaten Malaka. Kupang: PT. Secon Dwitunggal Putra.

Banazik, K., Krajewski, A., Sikorska, A.E. \& Ilejduk, L., 2014. Curve Number Estimation for a Small Urban Catchment from Recorded RainfallRunoff Events. Archives of Environmental Protection, 40(3), pp. 75-86.

Chow, V., Maidment, M. \& Mays, L., 1998. Applied Hydrology. New York: McGraw-Hill.

Delani, O.M. \& Dasanto, B.D. 2016. Comparison of Discharge Hydrograph Using Some Methods of Effective Rainfall (Case Study: Upper Cisadane Watershed). Jurnal Sumber Daya Air, 12(2), pp. $187-198$.

Directorate of Environmental Geology. 1983. Hydrogeological Map of Indonesia 1:250.000. Lembar: Timor.

Krisnayanti, D.S., Bunganaen, W., Frans, J.F., Seran,Y.A. \& Legono, D., 2021. Curve Number Estimation for Ungauged Watershed in SemiArid Region. Civil Engineering Journal, 7(6), pp.10701083 
McCuen, R. H., 1998. Hydrologic Analysis and Design (2nd ed.). New Jersey: Prentice-Hall.

Mishra, S.K., Gajbhiye, S. \& Pandey, A., 2013. Estimation of Design Runoff Curve Numbers for Narmada Watersheds (India). J Appl Water Eng Res, 1(1), pp. 69-79

Moglen, G.E., 2000. Effect of Orientation of Spatially Distributed Curve Numbers in Runoff Calculations. I Am Water Res Assoc, 36(6), pp. 1391-1400

NEH (National Engineering Handbook), 2004a. Chapter 7: Hydrologic Soil Groups, Part 630 Hydrology National Engineering Handbook, Washington DC: USDA.

NEH (National Engineering Handbook), 2004b. Chapter 9: HydrologicSoil Cover Complexes, Part 630 Hydrology National Engineering Handbook, Washington DC: USDA.

Ponce V.M., 1989. Engineering Hydrology Principles and Practices, New Jersey: PrenticeHall, Englewood Cliffs.

Ramadan, A.N.R., Adidarma, W.K., Riyanto, B.A. \& Windiantita, K., 2017. Determination of Hydrologic Soil Group for The Calculation of Floods at Upper Brantas watershed. Jurnal Sumber Daya Air, 13(2), pp. 69-82.

Rao, N.K., 2020. Analysis of Surface Runoff Potential in the Ungauged Basin Using Basin Parameters and SCS-CN Method. Applied Water
Science, 10:47. https://doi.org/10.1007/s13201019-1129-z

Sarminingsih, A., Rezagama, A. \& Ridwan, 2019. Simulation of Rainfall-runoff process using HEC HMS model for Garang Watershed, Semarang, Indonesia. IOP Conf. Series: Journal of Physics: Conf. Series 1217 (2019) 012134.

Sene, K., 2008. Flood Warning, Forecasting, and Emergency Response. United Kingdom: Springer Science

Suhartanto, E., 2008. Panduan HEC-HMS dan Aplikasinya di Bidang Teknik Sumber Daya Air. Malang. CV Citra.

Tivianton, T.A., 2008. Analisis Hidrograf Banjir Rancangan terhadap Perubahan Penggunaan Lahan dalam berbagai Kala Ulang Metode HujanLimpasan dengan HEC-GeoHMS dan HEC-HMS. Studi Kasus: Daerah Aliran Sungai Garang, Provinsi Jawa Tengah. Master Thesis Report. Department of Civil and Environmental Engineering, Universitas Gadjah Mada.

Triatmodjo, B.,2008. Hidrologi Terapan. Yogyakarta: Beta Ofset.

USACE. 2000. HEC-HMS Technical Reference Manual. USACE-HEC., Davis, CA.

ZeenatAra \& Zakwan, M., 2018. Estimating Runoff Using SCS Curve Number Method. International Journal of Emerging Technology and Advanced Engineering, 8(5), pp. 195-200 
[This page is intentionally left blank] 